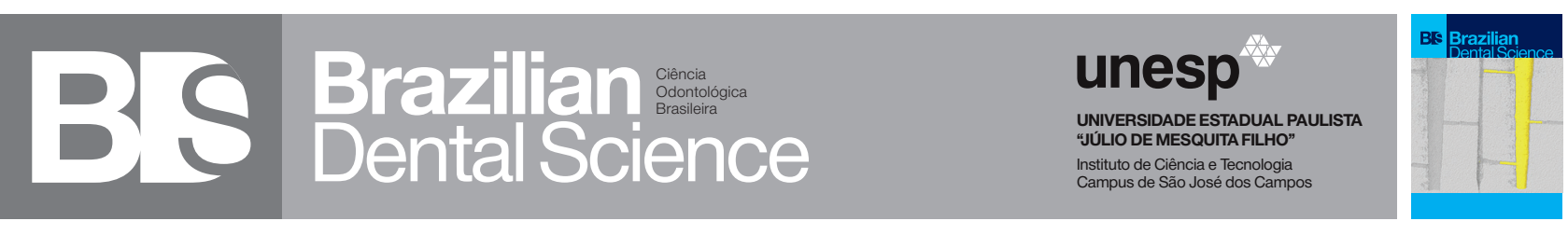

\title{
Effect of enamel pretreatment on the fluoride remineralization of artificial white spot lesions
}

\author{
Efeito do pré-tratamento do esmalte na remineralização de lesões brancas de cárie artificiais com fluoreto \\ Diana Ferreira Gadelha de ARAÚJO ${ }^{1,2}$,Fernanda Sandes de LUCENA ${ }^{1}$, Maria Cristina Carvalho de Almendra FREITAS ${ }^{1,3}$, Larissa \\ Vasconcellos NUNES ${ }^{1}$, Marília Mattar de Amoêdo Campos VELO ${ }^{1}$, Ana Carolina MAGALHÃES ${ }^{4}$, Linda WANG ${ }^{1}$ \\ 1 - Department of Operative Dentistry, Endodontics and Dental Materials - Bauru School of Dentistry - University of São Paulo - Bauru - SP - Brazil. \\ 2 - Department of Odontology - Federal University of Rio Grande do Norte - Natal - RN - Brazil. \\ 3 - DeVry FACID - DeVry Education Group - Teresina - PI - Brazil. \\ 4 - Department of Oral Biology - Bauru School of Dentistry - University of São Paulo - Bauru - SP - Brazil.
}

\section{ABSTRACT}

Objective: The topical fluoride application is the main strategy to remineralize white spots lesions (WSL). It is assumed that increasing its retention in the surface can favor remineralization. Therefore, previous treatments of the enamel surface are purposed to optimize its efficacy. This study aimed to evaluate the remineralization capacity of the fluoride without and with the pre-treatment of the enamel with phosphoric acid and aluminum nitrate and then, the enamel acid-resistance after new acid challenge. Material and Methods: Twenty-four enamel bovine blocks were obtained and selected by means of initial surface microhardness (SMH) measurements. In sequence, WSL were artificially inducted by DE-RE cycling and randomized in two groups according to the enamel pretreatment to be tested ( $\mathrm{n}=12)$ : $\mathrm{F}$ (1.23\% fluoride gel - APF- 4min) and P-Al-F (37\% phosphoric acid- 30s + $0.05 \mathrm{M}$ aluminum nitrate $1 \mathrm{~min}+\mathrm{APF}-4 \mathrm{~min})$. After then, a new acid challenge was equally performed. Additional $\mathrm{SMH}$ assessments were performed in each step. The values were processed and the percentage of SH loss (\%SHL) was obtained. Data were statically analyzed by two-way ANOVA and Tukey tests $(\mathrm{p}<0.05)$. Results: There was no difference between evaluated protocols. For both groups, a significant difference among the steps of study was detected: it was observed a decrease of $\%$ SHL after the treatment and increase of \%SHL after the new acid challenge. Conclusion: Enamel pretreatment with phosphoric acid associated with aluminum nitrate promoted similar protective effect compared to fluoride itself on the remineralization of artificial WSL, partially recovering the surface hardness. After new challenge, they also offered partial resistance..

\section{KEYWORDS}

Dental caries; Dental enamel; Fluoride; Tooth remineralization.

\section{RESUMO}

Objetivos: A aplicação tópica de flúor é a principal estratégia para remineralizar lesões de mancha branca (MB). Foi proposto que o aumento na retenção deste íon na superfície pode favorecer a remineralização. Portanto, o tratamento prévio da superfície do esmalte foi proposto para otimizar sua eficácia. Material e Métodos: Este estudo objetivou avaliar a capacidade de remineralização do fluoreto com e sem pré-tratamento do esmalte com ácido fosfórico e nitrato de alumínio e a resistência do esmalte após novo desafio ácido. Vinte e quatro blocos de esmalte bovino foram obtidos e selecionados pela média inicial de microdureza de superfície (MS). Em seguida, MB foram artificialmente induzidas através de ciclagem DES-RE e os espécimes aleatorizados em dois grupos de acordo com o pré-tratamento do esmalte a ser avaliado $(\mathrm{n}=12)$ : $\mathrm{F}$ (flúor gel acidulado 1,23\% - APF - 4 min) e P-Al-F (ácido fosfórico 37\% - 30s + nitrato de alumínio 0,05M 1min + APF por $4 \mathrm{~min}$ ). Após o tratamento, um novo desafio ácido semelhante ao inicial foi realizado. Novas avaliações de MS foram obtidas em cada etapa. Os valores foram processados e a porcentagem de perda mineral da superfície (\%PDS) foi obtida. Os dados foram analisados estatisticamente por ANOVA dois critérios e teste de Tukey $(p<0,05)$. Resultados: Não houveram diferenças entre os protocolos avaliados. Para ambos grupos, uma diferença significante entre as fases do estudo foi detectada: observouse uma queda no \%PDS após o tratamento e aumento do \%PDS após novo desafio ácido. Conclusão: $O$ pré-tratamento do esmalte com ácido fosfórico associado com nitrato de alumínio promoveu efeito similar à aplicação isolada do APF na remineralização das MB artificiais, recuperando parcialmente a dureza de superfície. Após o novo desafio ácido, os dois grupos ofereceram resistência parcial.

\section{PALAVRAS-CHAVE}

Cáries dental; Esmalte dentário; Fluoreto; Remineralização dentária. 


\section{INTRODUCTION}

$\nabla$ he remineralization of non-cavitated 1 incipient lesions associated with the control of etiologic factors is the early way to reestablish the integrity of the tooth structure caused by caries disease and reverse this scenario [1-3]. For this purpose, fluoride-base compounds are the most investigated and used agents themselves or associated [4,5]. Different strategies to optimize the fluoride retention can be suggested aiming to favor the remineralizing action under unbalanced situation, in attempt to provide fluoride easily.

The white-spot lesions (WSL) correspond to subsurface alterations of the enamel caused primarily by the loss of calcium and phosphate ions, which are characterized by increased porosity among the hydroxyapatite crystals [6]. In in vitro studies, the WSL can be induced through different protocols $[7,8]$. Among them, the DE-RE cycling is based on alternated cycles of demineralization and remineralization, close to more realistic conditions of caries lesions development in a dynamic process [7].

The fluoride application still demonstrates superior efficiency in comparison with other options to treat WSL $[4,5,9,10]$. Its predominant mode of action assumes the involvement of remaining fluoride from different topical sources ion working in conjunction with calcium and phosphate available in the oral environment to rebalance the remineralization process [11]. When available, fluoride is stored in the form of calcium fluoride (CaF2). In acidic challenge situations, the decrease of the $\mathrm{pH}$ triggers its reservoir and promotes its dissociation, releasing fluoride ions.

However, the main limitation of the CaF2 is its instability $[12,13]$. Investigations look for more stable complexes, aiming to improve the retention of fluoride in tooth structure and therefore, some different strategies are investigated [12-16]. Among them, the etching of the enamel with phosphoric acid and the application of aluminum nitrate were suggested [16-18].
The main role of $37 \%$ phosphoric acid gel in this process is about its ability to remove the outer layer of enamel and creates porosities in the inter-prismatic spaces [16]. The use of the aluminum in the enamel before the fluoride application was advocated due to the supply of metal complexes. As aluminum binds to fluoride, this complex would allow its higher retention $[16,18]$.

Thus, the protocol of remineralization of WSL with fluoride using the pre-treatment of the enamel surface might be an alternative to improve the clinical results in comparison to fluoride gel itself. The actual effect of these substances remains unclear, especially in conjunctively action, since few studies are available in the literature. This study aimed to compare the effect of the pre-treatment of the enamel with $37 \%$ phosphoric acid and aluminum nitrate in the remineralization process with $1.23 \%$ fluoride (APF) gel. The null hypotheses tested were that: 1 - the surface hardness loss (\%SHL) shows no differences among the steps of the study and 2- there were no differences in the \%SHL when the pre-treatment of the enamel was applied before the use of APF gel.

\section{MATERIAL AND METHODS}

\section{Experimental Design}

This in vitro study involved the analysis of two factors, enamel pre-treatment before fluoride application (yes or no) and different stages of this application. The loss of surface microhardness (\%SHL) was used as the main response variable.

Specimen preparation and induction of artificial enamel caries lesions

Twenty-four bovine incisors without decalcifications, hypoplasia, several wear or fracture were selected and stored in $0.1 \%$ thymol-supersaturated saline solution at $4^{\circ} \mathrm{C}$. Teeth were cut using Isomet low-speed saw (Buehler, Lake Bluff, IL, USA) and two diamond discs (Extec Corp, Enfield, CT, USA). Enamel blocks ( $6 \times 4 \times 2 \mathrm{~mm})$ were obtained and a sequential polishing was performed allowing 
the selection by the initial Knoop surface microhardness (SMH1), using 25g load during 10s (MicroMet 6040, Buehler, Lake Bluff, IL, USA). These selected blocks were prepared $(350 \mathrm{KHN}+10 \%)$ and a protection of $1.5 \mathrm{~mm}$ of one of the extreme surface was done using nail polish. This dimension allowed $1.5 \mathrm{~mm}$ of surface for each considered tested situation in the same specimen.

To obtain standardized artificial caries lesions, DE-RE cycling was performed during 7 days [7]. The compositions of the solutions used for the cycling are presented in the Table 1. During 5 days, the specimens were immersed in demineralization and remineralization solutions respectively for 6 and $18 \mathrm{~h}$. In the last 2 days, the specimens were maintained exclusively in remineralization solution. Before the induction of these artificial lesions, the used protocol was validated using two additional blocks, which were subjected to the same DE-RE cycling and analyzed using the transversal microradiography (TMR). After the DE$\mathrm{RE}$ cycling, new assessment of $\mathrm{SH}$ was obtained at the demineralized area of the specimens of the study (SMH2). New coat of nail varnish was then applied onto this assessed surface.

Table 1 - Composition of solutions used for DE-RE cycling

\begin{tabular}{|c|c|}
\hline Demineralization solution (pH 4.7) & $\begin{array}{c}2.0 \mathrm{mM} \mathrm{Ca}\left(\mathrm{NO}_{3}\right)_{2} \cdot 4 \mathrm{H}_{2} \mathrm{O} \\
2.0 \mathrm{mM} \mathrm{NaH}_{2} \mathrm{PO}_{4} \cdot 2 \mathrm{H}_{2} \mathrm{O} \\
0.077 \mathrm{mM} \text { acetate buffer } \\
0.02 \mathrm{ppmF}\end{array}$ \\
\hline Remineralization solution (pH 7.0) & $\begin{array}{c}1.5 \mathrm{mM} \mathrm{Ca}\left(\mathrm{NO}_{3}\right)_{2} \cdot 4 \mathrm{H}_{2} \mathrm{O} \\
0.9 \mathrm{mM} \mathrm{NaH} \mathrm{HO}_{4} \mathrm{PO}_{4} \cdot 2 \mathrm{H}_{2} \mathrm{O} \\
150 \mathrm{mMM} \mathrm{KCl} \\
0.1 \mathrm{~mol} / \mathrm{I} \text { Tris buffer } \\
0.03 \mathrm{ppm} \mathrm{F}\end{array}$ \\
\hline
\end{tabular}

\section{acid challenge \\ Protocols of enamel pretreatment and new}

According to the SH1, the specimens were randomized in two groups $(n=12)$ for the treatment of the WSL, regarding association without or with the purposed pretreatment of the enamel. The description of the groups and their treatment protocols were described in Table 2. The treatment was performed during four weeks, at weekly intervals, resulting in 4 applications. Immediately after each application, the specimens were immersed in individual vials containing $30 \mathrm{ml}$ of artificial saliva (Table 3), and stored at $37^{\circ} \mathrm{C}$, which were weekly renewed.

Table 2 - Protocols of enamel preatreatment tested on this study

\begin{tabular}{|c|c|}
\hline$F$ & $\begin{array}{c}\text { Application of } 1.23 \% \text { fluoride gel (APF) for } 4 \text { min; removal of } \\
\text { excess }\end{array}$ \\
\hline $\mathrm{CA}$ & $\begin{array}{l}\text { Enamel etching with } 37 \% \text { phosphoric acid (30s); washing and } \\
\text { drying (20s); application of } 0.05 \mathrm{M} \text { aluminum nitrate ( } 1 \mathrm{~min} \text { ) } \\
\text { with removal of excess; application of } 1.23 \% \text { fluoride gel (APF) } \\
\text { for } 4 \mathrm{~min} \text {; removal of excess }\end{array}$ \\
\hline
\end{tabular}

Table 3 - Composition of artificial saliva

$0.70 \mathrm{mM} / \mathrm{L} \mathrm{CaCl} 2$
$0.20 \mathrm{mM} / \mathrm{L} \mathrm{MgCl} 2.6 \mathrm{H} 20$
$4.00 \mathrm{mM} / \mathrm{L} \mathrm{KH} 2 \mathrm{PO} 0$
$30.0 \mathrm{mM} / \mathrm{L} \mathrm{KCl}$
$0.30 \mathrm{mM} / \mathrm{L} \mathrm{NaN3}$
$20.0 \mathrm{mM} / \mathrm{LHEPES}$ (acid) buffer

After the treatment, a new measurement of the SMH (SMH3) was performed in the treated area and a new protection with nail polish was made, resulting in the last unprotected surface. This area was subjected of a new acid challenge using the same DE-RE cycling protocol previously described and the final measurement of the SMH (SMH4) was performed.

\section{Statistical analysis}

The $\mathrm{SH}$ values were processed and a mean of the percentage of surface hardness loss (\% SHL) was obtained for each step. The assumptions of normal distribution and of equality of variances were checked for all the variables using Kolmogorov-Smirnov and Levene test, respectively. As the assumptions were satisfied, data was analyzed by two-way ANOVA and Tukey tests $(\mathrm{p}<0.05)$.

\section{RESULTS}

Means of \%SHL of both protocols and respective standard deviations were described in table 4. Statistical significance was detected regarding the factor step of study $(\mathrm{p}<0.001)$. However, it was not observed regarding or the factor pretreatment $(p=0.460)$ either their interaction $(p=0.354)$. 
Table 4 - Means and standard deviations of percentage of $\mathrm{SH}$ loss (\% SHL) among steps of study regarding the initial condition

\begin{tabular}{|c|ccc|}
\hline Protocol & I/D & I/T & I/N \\
\hline F & $-93.15(7.64) \mathrm{Aa}$ & $-41.98(18.02) \mathrm{Ba}$ & $-65.27(6.47) \mathrm{Ca}$ \\
\hline P-Al-F & $-95.48(2.12) \mathrm{Aa}$ & $-48.76(18.15) \mathrm{Ba}$ & $-62.27(6.71) \mathrm{Ca}$ \\
\hline
\end{tabular}

I= initial condition- control; $D=$ des-re cycling; $T=$ treatment; $N=$ new des-re cycling

$N=12$

Different lowercase letter indicate significant differences between treatments in the same step of study.

Different uppercase letter indicate significant differences among steps of study in the same treatment.

For each group, the comparison among the different steps of this study was always compared to its respective first measurement (SHM1), which revealed significant differences between I/D and I/T steps. Among the comparison of \%SHL for each condition, both purposed conditions were able to reduce the loss of surface hardness after treatment. However, it is notable that $\mathrm{I} / \mathrm{T}$ promoted less $\% \mathrm{SHL}$, which indicates capacity to reduce demineralization compared to I/D. After the new acid challenge (I/N), \%SHL slighted increased $\mathrm{n}$ compared to $\mathrm{I} / \mathrm{T}$, which suggest partially continuous loss of hardness. However, the final \%SHL was significant lower regarding the values obtained to I/D step.

\section{DISCUSSION}

The use of fluoride is described in previous studies as the main strategy to remineralize white spots lesions even new technologies and materials are routinely launched $[1,18-20]$. The increase of the retention of this material has been shown between its association with other metals or materials [14-16,18]. Thus, this study aimed to investigate the role of two previously preconized methods in association: APF with phosphoric acid and aluminum nitrate to treat white spot lesions targeting to a well-reactive surface to interact with fluoride. Based on the results of this study, the topical application of fluoride, irrespective to the pretreatment, was able to partially recover the surface hardness of the substrate, rejecting the first null hypothesis. However, as no differences were found between the two protocols of treatment used, the second hypothesis was accepted.

The enamel demineralization is related to sub-saturation condition of calcium and phosphate, resulting in the dissolution of the hydroxyapatite. This is a dynamic process and reproducible trough different laboratorial protocols $[7,8]$.

In the present study, the DE-RE cycling used produced a similar \%SHL for both groups, ensuring standardized conditions for the tested pretreatments.

The in vitro model to obtain incipient caries lesions used was partially based in the $\mathrm{pH}$ cycling described by Vieira et al. [7], since this protocol produced sub-surface lesions and simulates actual $\mathrm{pH}$ changes of the oral environment. The main difference in the protocol of the present study is the no renew of the solutions during the cycling as pilot tests performed before this study demonstrated that there were no differences in the enamel lesions features obtained with or without these changes. The \%SHL after the DE-RE cycling was greater than $90 \%$ and the values were similar to the obtained in a previous study [15], which also used this $\mathrm{pH}$ cycling model. Furthermore, the validation trough TMR performed in the present study also attested the creation of subsurface lesions.

The fluoride therapy was effective to improve resistance to continuous demineralization and reversion of this process, as it reduced the \%SHL in the previously demineralized surface. Possibly, the APF applied in the groups of this study supplied fluoride ions that reacted with calcium and phosphate ions, in which were provided by the artificial saliva used to storage the specimens. It is assumed that this combination resulted in the formation of fluorhidroxiapatite-like structure, which is incorporated into the partial demineralized apatite of the tooth structure [19]. Ingram et al. 
[20] suggested that the fluoride induces both crystal grow and preferential re-acquisition of calcium. Based on these exposed mechanisms, fluoride gel acts in favor the protection of enamel.

The main interactions between the oral environment and the incipient caries lesions occur in the surface layer of the tooth structure [21-23]. This behavior becomes the surface hardness tests a valid option to evaluate the relationships between fluoride and enamel $[23,24]$.

Under low $\mathrm{pH}$ scenario, these formed complexes onto enamel surface increase the availability of the fluoride ion, enhancing the remineralizing ability [21]. In the clinical possibilities of fluoride application, the APF is commonly used due to its availability, low cost and easy clinical application. In this case, as it presents a low $\mathrm{pH}$ (around 3.5 - 4.5), it may induce a discrete surface etching, increasing the surface roughness. Also, this etching may favor for the incorporation of fluoride onto the enamel [21]. On other hand, the low $\mathrm{pH}$ is more effective for this purpose in sound enamel or early lesions. In more advanced non-cavitated lesions, the low $\mathrm{pH}$ can negatively interfere in the remineralization process [25], indicating that lower values of \%SHL in the treatment step could have been observed if the initial values of surface hardness loss were not as higher as those achieved in this study.

In attempt to increase the fluoride retention, different strategies were described in previous studies $[14,15,17,18]$. Among these strategies, the use of phosphoric acid [17] and aluminum $[16,18]$ was associated in this study as a pre-treatment of the enamel, aiming enhance the fluoride potential of remineralization based on these two interesting methods. The aluminum in the form of aluminum nitrate facilitates its dissociation, and thus would allow the link with the fluoride ions.

Following a previous study [17], the enamel etching with phosphoric acid removes the outer layer of mineral, increasing the surface porosity and consequently promotes a better diffusion of ions until the sub-surface area of the lesion. The aluminum creates metal complexes with the fluoride ions that establish strong chemical bonds with the phosphate groups in the surface of the mineral, protecting the structure of the action of the hydroxyl ions [18]. Despite the benefits described in the literature and attested in this study, the association of these methods did not result in effective increase of remineralization compared to the use of only APF. This absence of enhanced positive performance may be attributed with the low pH of the APF, which also may be promoted an etching of the surface [26]. Furthermore, the previous acid etching of the enamel seems to hamper the formation of the complex between fluoride and aluminum. As the other investigations using this association with positive perspectives did not report the $\mathrm{pH}$ of APF gel, it could determine the differences among these studies.

The literature describes a positive effect and enhance of the remineralization when the fluoride was associated with metal ions [16-18]. However, in the in situ study of Alcântara et al. [26], the application of titanium tetrafluoride did not result in a better remineralization of artificial caries lesions compared with the protocol with sodium fluoride either. The similarity of performance was attributed to saliva, which is the main responsible of the ions change. Their results corroborated with the finds of the present study and claim for more investigations.

The use of fluoride is also described to prevent further loss of mineral when the structure is subjected to new acid challenges [15]. Under a new challenge, the reservoir of fluoride (CaF2) is dissociated, releasing fluoride ion to act in the remineralization process [22]. In the present study, the $\mathrm{I} / \mathrm{N}$ step showed a $\%$ SHL higher than I/T step, but lower compared with the I/D step, indicating that the treatment prevented further loss of hardness, being both relevant and validated treatments of early noncavitated lesions. 


\section{CONCLUSIONS}

Within the limitations of this study, the application of $1.23 \%$ APF was able to recover the surface hardness and, despite the \%SHL after the new acid challenge, the treatment used protected the enamel. The pretreatment did not exhibit a complete gain of the surface hardness but was able to minimize its reduction as well as performed when APF was used solely. Researchers and clinicians still need to search for approaches for enamel remineralization that could be effective with prolonged remineralization effect, exploring natural agents or conciliating available methods [19,27]. It still is necessary to stablish that the different advances can serve for different population, regarding preventive and/ or early treatment.

\section{ACKNOWLEDGEMENTS}

This study was supported by CAPES Brazilian governmental support. Authors are also grateful for Larissa Tercilia Grizzo for laboratorial support.

\section{REFERENCES}

1. Kantovitz KR, Capa AMC, Sacramento PA, Gavião MBD, Puppin-Rontani RM, Pascon FM. A clinical report of functional and esthetic oral rehabilitation in a high-caries-risk child: one-year follow-up. Braz Dent Sci. 2016;19(1):125-8.

2. Melgar RA, Pereira JT, Luz PB, Hugo FN, Araujo FB. Differential impacts of caries classification in children and adults: a comparison of ICDAS and DMF-T. Braz Dent J. 2016;27(6):761-6.

3. Restrepo M, Bussaneli DG, Jeremias F, Cordeiro RC, Raveli DB, Magalhães AC, et al. Control of white spot lesions with use of fluoride varnish or chlorhexidine gel during orthodontic treatment: a randomized clinical trial. J Clin Pediatr Dent. 2016;40(4):274-80

4. EsenlikE,Uzer ÇelikE, BolatE Efficacy of a casein phosphopeptide amorphous calcium phosphate (CPP-ACP) paste in preventing white spot lesions in patients with fixed orthodontic appliances: A prospective clinical trial. Eur J Paediatr Dent. 2016;17(4):274-80.

5. Turska-Szybka A, Gozdowski D, Mierzwi ska-NastalskaE,Olczak-Kowalczyk D. Randomised clinical trial on resin infiltration and fluoride varnish vs fluoride varnish treatment only of smooth-surface early Caries lesions in deciduous teeth. Oral Health Prev Dent. 2016;14(6):485-91.

6. Robinson C. Fluoride and the caries lesion: interactions and mechanism of action. Eur Arch Paediatr Dent. 2009;10(3):136-40.

7. Vieira AE, Delbem AC, Sassaki KT, Rodrigues E, Cury JA, Cunha RF.Fluoride dose response in $\mathrm{pH}$-cycling models using bovine enamel. Caries Res. 2005:39(6):514-20.
8. Magalhães AC, Moron BM, Comar LP,Wiegand A, Buchalla W, Buzalaf MA. Comparison of cross-sectional hardness and transverse microradiography of artificial carious enamel lesions induced by different demineralizing solutions and gels. Caries Res. 2009;43(6):474-83.

9. Attin T, Hartmann O, Hilgers RD, Hellwig E. Fluoride retention of incipient enamel lesions after treatment with a calcium fluoride varnish in vivo. Arch Oral Biol. 1995;40(3):169-74.

10. Mesinkai PK, Ccahuana-Vasquez RA, Chedjieul,Amaechi BT, Mackey AC, Walker TJ, etal. In situ remineralization of white-spot enamel lesions by 500 and 1,100 ppm F dentifrices. Clin Oral Investig. 2012:16(4):1007-14.

11. Fejerskov 0, Clarkson BH. Dynamics of caries lesion formation. In: Fejerskov 0, Ekstrand J, Burt BA. Fluoride in dentistry. Copenhagen: Munksgaard; 1996. p. 187-229.

12. Falcão A, Masson N, Leitão TJ, Botelho JN, Ferreira-Nóbilo Nde P, Tabchoury CP, et al. Fluoride rinse effect on retention of $\mathrm{CaF} 2$ formed on enamel/dentine by fluoride application. Braz Oral Res. 2016;30. pii:S1806-83242016000100802. doi:10.1590/1807-3107BOR-2016.vol30.0031.

13. Øgaard B.CaF2 formation: cariostatic properties and factors of enhancing the effect. Caries Res. 2001;35 Suppl 1:40-4.

14. Alves KM, Franco KS, Sassaki KT, Buzalaf MA, Delbem AC. Effect of iron on enamel demineralization and remineralization in vitro. Arch Oral Biol. 2011;56(11):1192-8.

15. Comar LP, Wiegand A, Moron BM, Rios D, Buzalaf MA, Buchalla W, etal. In situ effect of sodium fluoride or titanium tetrafluoride varnish as solution on carious demineralization of enamel. Eur J Oral Sci. 2012;120(4):342-8.

16. Koletsi-KounariH, Mamai-HomataE, Diamanti I. An in vitro study of the effect of aluminum and the combined effect of strontium, aluminum, and fluoride elements on early enamel carious lesions. Biol Trace Elem Res. 2012 Jun;147(13):418-27.

17. Al-Khateeb S, Exterkate R, Angmar-Mansson B, ten Cate JM. Effect of acidetching on remineralization of enamel white spot lesions. Acta Odontol Scand. 2000;58(1):31-6.

18. Hö̈k M, Christoffersen J,Christoffersen MR, Leonardsen ES, Rassing MR, Rostrup E. Effects of aluminum (III) and fluoride on the demineralization of bovine enamel: a longitudinal microradiographic study. Scand J DentRes. 1994;02(4):198-201

19. Abdullah Z, John J. Minimally Invasive Treatment of White Spot Lesions -A Systematic Review. Oral Health Prev Dent. 2016;14(3):197-205.

20. Ingram GS, Agalamanyi EA, Higham SM. Caries and fluoride processes. J Dent. 2005;33(3):187-91

21. Lee YE, Baek HJ, Choi YH, Jeong SH, Park YD, Song KB. Comparison of remineralization effect of three topical fluoride regimes on enamel initial carious lesions. JDent. 2010;38(2):166-71.

22. Buzalaf MA, Whitford GM. Fluoride metabolism. Monogr Oral Sci. 2011;22:2036. do: 10.1159/000325107.Epub 2011 Jun 23.

23. Rehder Neto FC, Maeda FA, Turssi CP,Serra MC. Potential agents to control enamel caries-like lesions. J Dent. 2009;37(10):786-90.

24. Cury JA, Simões GS, Del Bel Cury AA, Gonçalves NC, Tabchoury CP.Effect of a calcium carbonate-based dentifrice on in situ enamel remineralization. Caries Res. 2005;39(3):255-7.

25. González-Cabezas C, Jiang H, Fontana M, Eckert G. Effect of low pH on surface rehardening efficacy of high concentration fluoride treatments on noncavitated lesions. JDent. 2012;40(6):522-6. 
26. Alcântara PC,Alexandria AK, Souza IP,Maia LC. In situ effect of titanium tetrafluoride and sodium fluoride on artificially decayed human enamel. Braz Dent J.2014;25(1):28-32.
27. DeLuca MP,Freires IA, Gala-García A, Santos VR, ValeMP,Alencar SM, etal. The anti-caries activity and toxicity of an experimental propolis-containing varnish. Braz Oral Res. 2017 Jun 5;31:e45. doi:101590/1807-3107BOR-2017. vol31.0045.

\section{Prof. Dr. Linda Wang}

(Corresponding address)

Department of Operative Dentistry, Endodontics and Dental Materials

Bauru School of Dentistry-FOB-USP

Alameda Octávio Pinheiro Brisolla, 9-75

Date submitted: 2018 Apr 11

E-mail: wang.linda@usp.br 